\title{
PENGGUNAAN BAHASA MADURA YANG DIGUNAKAN OLEH ORANG TUA TERHADAP KARAKTER SISWA DI SDN CANDI I
}

\author{
Ahmad Wahid Fudhaily, Nisfil Maghfiroh Meita \\ Universitas Wiraraja \\ wahidfdl92@gmail.com,nisfil@wiraraja.ac.id
}

\begin{abstract}
Abstrak
Siswa Kelas IV, V, dan VI SDN Candi I tidak selalu menggunakan bahasa madura yang halus Engghi Enten dalam berkomunikasi sebagaimana diajarkan orang tuanya. Sedangkan karakternya masih tergolong baik dan bagus. Penelitian ini bertujuan untuk mengetahui hubungan bahasa Madura yang digunakan oleh orang tua terhadap karakter siswa Kelas IV, V, dan VI di SDN Candi I dengan menggunakan teknik wawancara, observasi, dokumentasi, rekaman dan triangulasi. Adapun instrument yang digunakan adalah pedoman wawancara, lembar observasi, dan dokumentasi. Triangulasi yang digunakan pada penelitian ini adalah Triangulasi Waktu (periode I 10-14 Juli 2020 dan periode II 10-14 Juli 2020), Sumber dan Teknik. Sumber utama pada penelitian ini dalah Siswa Kelas IV, V dan VI, dan sumber keduanya adalah orang tua dan guru kelas. Teknik yang digunakan saat triangulasi adalah wawancara, observasi dokumentasi dan rekaman. Berdasarkan data yang diperoleh diketahui bahwa hubungan bahasa yang digunakan oleh orang tua dengan karakter toleransi, bersahabat atau komunikatif, dan peduli sosial pada Kelas IV, V, dan VI sangat berpengaruh terutama pada karakter bersahabat atau komunikatif. Hasil penelitian ini menunjukkan semakin baik bahasa yang digunakan oleh orang tua maka karakter siswa akan semakin baik pula terutama pada karakter bersahabat atau komunikatif.
\end{abstract}

Kata Kunci: Bahasa Madura, Orang Tua, Karakter

\begin{abstract}
The grade IV, V, and VI students in SDN Candi 1 do not always use the good Madurese (Engghi-Enten) in communicating as taught as their parents. Meanwhile, the characters of the student are still good. This research aims to determine the relationship between the Madurese used by parents to the character of students in IV, V, and VI Grades at SDN Candi 1 with using interviews, observation, documentation, recording, and triangulation techniques. The instruments used is interview guides, observation sheets, and documentation. The triangulation used in this study is the Triangulation of Time (first-period 30 June to 01 July 2020 and the second period 10 to 14 July 2020), Resources, and Techniques. The main objects in this study were students in IV, V, and VI grades, and the second objects were parents and class teachers. The triangulation techniques were interviews,
\end{abstract}


observation documentation, and recordings. Based on the data obtained, it shows that the relationship between the language used by parents with the characters of tolerance, friendly or communicative, and social care in IV, V, and VI grades are significant especially in communicative and friendly character. This research shows the better the language used by parents, the better the student's character will be, especially in friendly or communicative characters. taught at the elementary school level. Integrating curriculum, teacher motivation, community involvement, and providing access to information technology are effective factors to improve understanding of financial literacy. Curriculum and teaching materials are adjusted based on field findings designed by relevant stakeholders, especially educational actors and social communities. Financial literacy content standards as development inclusive finance that is, students can understand the relationship between education, career and lifestyle and the development of skills needed for financial targets.

Keywords: Madurese (Language of Madura), Parents, Character

\section{PENDAHULUAN}

Bahasa Madura merupakan bahasa yang digunakan oleh Masyarakat Madura pada umumnya dan Sumenep khususnya sebagai alat berkomunikasi sehari-hari. Seperti yang tertulis dalam esai Dian Palupi pada buku Kongres I Bahasa Madura (2008) bahwa Bahsa Madura digunakan di empat wilayah kabupaten di pulau Madura, yakni Kabupaten Panekasan, Kabupaten Sumenep, Kabupaten Sampang, Kabupaten Bangkalan serta pulaupulau disekitarnya seperti Sapudi, Raas, Kambing, dan Kangean.

Desa Candi merupakan salah satu desa yang terletak di Kecamatan Dungkek kabupaten Sumenep. Keseharian masyarakat desa Candi rata-rata menggunakan bahasa madura untuk melakukan komunikasi dengan anak-anaknya. Namun bahasa yang digunakan hanya sampai bahasa tingkat menengah atau bahasa Engghi-Enten. Hal itu disebabkan karena biasanya bahasa madura tingkat tinggi digunakan oleh orang bawah kepada orang yang lebih tinggi seperti kepada kiai. Bahasa tingkat tinggi biasanya hanya digunakan pada orang-orang kerajaan pada zaman dahulu. Seperti yang sudah disampaikan dalam buku Malathe Sato'or (Tajib, 1986) bahwa bahasa Enggi-Bunten digunakan oleh orang tua dengan orang tua yang lain, orang berpangkat dengan orang yang berpangkat yang lain, atau orang agung dengan orang agung yang lain.

Pada umumnya semakin baik bahasa yang digunakan maka semakin baik pula karakter seorang tersebut. Seperti yang disampaikan oleh Hermawan dalam Wiyani (2013) bahwa karakter adalah ciri khas yang dimiliki oleh suatu benda atau individu. Kemudian pada tahun 2010 Mendiknas menetapkan bahwa terdapat 18 macam karakter. Dengan 18 
macam karakter yang juga harus diajarkan serta dilatih oleh guru dan orang tua, diharapkan nantinya siswa dapat memfilter pengaruh yang tidak baik dan benar-benar layak menjadi harapan di genarasi emas.

Lickona dalam Ekosiswoyo (2017) mengemukakan bahwa karakter yang baik yaitu mencakup tentang pengetahuan yang baik (pengetahuan moral) dan kemudian menumbuhkan komitmen atau niat untuk menjadi lebih baik dan dibuktikan dengan benarbenar berbuat baik. Seperti memiliki nilai karakter toleransi, bersahabat atau komunikatif dan peduli sosial.Karakter tersebut merupakan salah satu nilai penting yang harus ditanamkan sejak dini kepada seorang anak.

Oleh karena itu seorang guru harus selalu menanamkan nilai-nilai karakter sebagaimana yang telah dicantumkan dalam perpes No 87 tahun 2017 tentang penguatan pendidikan karakter. Karena menurut Jean Peaget pada anak usia 7 tahun akan memasuki tahap operasional konkret, dimana anak sudah mampu berpikir rasional, seperti penalaran untuk menyelesaikan suatu masalah yang aktual. Pada saat itu adalah saat yang tepat untuk mengajari anak bertoleransi, peduli sosial dan komunikatif. Karena dengan siswa memliki minimal tiga karakter tersebut, sudah dapat membuktikan bahwa siswa memiliki EQ yang baik. Tidak hanya dari guru saja, namun orang tua juga berperan penting dalam pembentukan karakter tersebut. Salah satu contohnya adalah dengan manggunakan bahasa yang baik sesuai dengan aturan di daerahnya masing-masing

Akan tetapi berdasarkan hasil observasi yang dilakukan pada November 2019 diketahui bahwa siswa Kelas IV, V, dan VI di SDN Candi I tidak selalu menggunakan bahasa yang baik, dan tidak bertanggung jawab terhadap bahasa yang diajarkan oleh orang tuanya. Dalam artian tidak menjalankan atau mengaplikasikan bahasa madura yang halus dalam berkomunikasi. Sedangkan karakter yang dimiliki oleh siswa masih tergolong baik dan bagus. Sementara menurut Solin (2010) menyatakan bahwa semakin baik penggunaan bahasa dan semakin teliti pilihan bahasa yang digunakan maka semakin bagus pula karakternya. Maka dari itu tulisan ini akan membahas tentang hubungan bahasa Madura yang digunakan oleh orang tua terhadap karakter siswa di SDN Candi I.

\section{METODE}

Jenis penelitian deskriptif kualitatif dikarenakan penelitian ini bersifat untuk mendapatkan data yang mendalam dan mengandung makna. Penelitian ini akan diselesaikan dalam waktu kurang lebih enam bulan terhitung dari bulan Februari sampai dengan bulan Juli 2020 di SDN Candi I, Kec. Dungkek, Kab. Sumenep, Prov. Jawa Timur. Penelitian ini akan diselesaikan dalam waktu kurang lebih enam bulan terhitung dari bulan Februari sampai dengan bulan Juli 2020 di SDN Candi I, Kec. Dungkek, Kab. Sumenep, Prov. Jawa Timur. 
Penelitian ini akan diselesaikan dengan menggunakan teknik wawancara, observasi, dokumentasi, rekaman dan triangulasi. Data dari penelitian ini akan diperoleh dari data primer dan data sekunder. Dimana data primernya adalah siswa kelas IV, V dan Kelas VI SDN Candi I, sedangkan data sekundernya adalah orang tua, dan guru. Alat bantu yang digunakan untuk mengumpukan data adalah menggunakan pedoman wawancara, lembar observasi, dokumentasi dan alat perekam. Proses analisis data akan dilakukan dengan tahap reduksi data, penyajian data, triangulasi data, dan kesimpulan. Uji kredibilitas data atau triangulasi yang akan dilakukan adalah triangulasi sumber, waktu, dan teknik.

Adapun indikator dari Toleransi adalah Menghargai satu sama lain, menghargai perbedaan orang lain, menghargai diri sendiri, dan menghargai kebaikan orang lain, Supriyanto (2017). Indikator dari aspek komunikatif yaitu mengerjakan pekerjaan kelompok, Bergaul dengan teman kelas, bergaul dengan teman lain kelas/ tidak memilihmilih teman, serta berbicara dengan guru, kepala sekolah, dan personalia lainnya, Utami (2017). Sementara indikator dari Peduli Sosial adalah Tenggang rasa, Mengembalikan barang temuan/ berakhlak mulia, tolong menolong, dan berbagi dengan teman/ aksi sosial, Sutarna (2018).

Untuk mengetahui kategori karakter siswa, ketika observasi peneliti diminta untuk mencentang indikator apa saja yang dilakukan oleh siswa. Setiap indikator memiliki skor 1, apabila tidak mengerjakan indikator mendapat 0. Kemudian skor yang diperoleh dijumlahkan dan dibagi total skor (12) lalu dikalikan 100. Jumlah sekor akhir dari seluruh indikator kemudian di konversi kedalam kategori sebagai berikut:

Tabel Kategori Berkarakter

\begin{tabular}{ccc}
\hline No & Sekor & Kategori \\
\hline 1 & $76-100$ & Membudaya (M) \\
\hline 2 & $51-75$ & Berkembang (B) \\
\hline 3 & $26-50$ & Mulai Berkembang (MBK) \\
\hline 4 & $1-25$ & Memerlukan Bimbingan (MB)
\end{tabular}

(Sumber: Kemendikbud, 2019)

\section{HASIL PENELITIAN DAN PEMBAHASAN}

Setelah data yang dibutuhkan diperoleh di lapangan, baik data yang diperoleh melalui hasil wawancara, observasi, dan dokumentasi yang dilakukan kepada siswa, orang tua, dan juga guru, kemudian peneliti akan menganalisis temuan yang diperoleh dan memodifikasi teori yang ada kemudian membangun teori baru serta menjelaskan kaitannya tentang penelitian penggunaan bahasa yang digunakan oleh orang tua terhadap karakter siswa Kelas IV, V, dan VI SDN Candi 1. 


\section{Penggunaan Bahasa Madura}

Maksud dari penggunaan bahasa Madura disini adalah bahasa Madura yang digunakan oleh orang tua untuk berkomunikasi dengan anaknya sehari-hari. Berdasarkan data yang diperoleh dari lapangan oleh peneliti, ditemukan bahwa bahasa yang digunakan adalah bahasa Madura. Adapun tingkatan bahasa yang digunakan adalah tingatan bahasa Enjha' Iye. Namun, orang tua mengajarkan kepada anaknya untuk selalu menggunakan bahasa Madura yang baik (Engghi Enten) ketika berbicara dengan orang lain. Akan tetapi anak terkadang masih tetap menggunakan bahasa Enjha' Iye kepada orang lain. Bahasa Engghi Enten digunakan oleh orang tua untuk berkomunikasi dengan orang lain terutama kepada orang yang lebih tua dan untuk memberikan contoh kepada anaknya.

Meskipun demikian terdapat orang tua yang juga menggunakan bahasa asing untuk berbicara kepada anaknya untuk melatih kemampuan anak dalam menggunakan bahasa asing. Adapun bahasa asing yang kadang-kadang digunakan adalah bahasa Arab dan bahasa Inggris. Namun bahasa tersebut jarang sekali digunakan oleh orang tua. Mereka hanya menggunakan di waktu-waktu tertentu saja. Seperti saat berkumpul di saat waktu yang segang.

Selain orang tua yang mengajari anaknya menggunakan bahasa Madura tingkatan Enjha' Iye dan Engghi Enten, ada guru yang juga mengajari anak dalam menggunakan bahasa tersebut. Guru yang berperan disini adalah guru di sekolah dasar dan juga guru di madrasah diniyan. Karena, kebanyakan anak juga sekolah ke madrasah, dimana disana juga diajari menggunakan bahasa yang baik (Engghi Enten) oleh guru-gurunya.

Sehingga bahasa yang digunakan oleh anak tidak sepenuhnya dipengaruhi oleh orang tua, tetapi juga dipengaruhi oleh guru meskipun hanya sebagian kecil saja. Karena anak lebih banyak menghabiskan waktu bersama orang tua dan mereka lebih banyak berkomunikasi dari pada dengan orang lain. Dengan demikian yang paling berperan dalam pemerolehan bahasa anak adalah bahasa yang digunakan orang tua yaitu tingkatan Enjha' Iye dan Engghi Enten.

\section{Karakter Siswa}

Seperti yang sudah peneliti sampaikan di BAB II bahwa terdapat 18 macam karakter. Dari 18 karakter yang ada, peneliti hanya meneliti tiga karakter saja, yaitu karakter toleransi, bersahabat atau komunikatif, dan juga peduli sosial. Karena ketiga karakter tersebut adalah karakter yang paling berhubungan dengan bahasa.

Kategori karakter yang ada di penelitian ini mengacu pada panduan pendidikan karakter kemendikbud 2019 yaitu Membudaya (M), Berkembang (B), Mulai Berkembang (MBK), dan juga Memerlukan Bimbingan (MB). Karena karakter tidak dapat dinilai dengan baik atau tidak baik, melainkan dengan berkembang atau membudayanya karakter 
tersebut. Karena salah satu tujuan ditanamkannya karakter adalah untuk bisa membudaya. Untuk mengetahui karakter seorang siswa berkategori apa dapat dihitung dengan cara skor yang diperoleh dijumlahkan dan dibagi total skor (12) lalu dikalikan 100. Kemudian hasil akhirnya dapat dilihat pada tabel 2.1.

Berdasarkan hasil penelitian yang telah dilakukan oleh peneliti, maka dapat diperoleh data bahwa siswa Kelas IV, V, dan VI SDN Candi 1 memiliki karakter yang membudaya sebagaimana telah peneliti sebutkan di atas. Walaupun ada beberapa siswa yang tiding melakukan semua indikator karakter yang diteliti. Namun hasil yang diperoleh masih berkategori membudaya. Akan tetapi, meskipun siswa tersebut membudaya di tiga karakter yang diteliti belum tentu juga siswa Kelas IV, V, dan VI SDN Candi 1 berkategori membudaya di karakter lain. Karena penelitian ini hanya fokus terhadap tiga karakter yang telah peneliti jelaskan di atas.

Adapun hubungan bahasa madura yang digunakan oleh orang tua dengan karkter toleransi yaitu Pada siswa kelas IV diperoleh bahwa bahasa yang digunakan masih tidak menggunakan bahasa yang baik (Engghi Enteng) saat berkomunikasi dengan orang lain. Bahkan masih ada siswa yang menggunakan bahasa Enjha' Iye kepada orang tuanya bahkan ada siswa yang tidak sepenuhnya menghargai orang lain seperti saat di ajak berbicara. Anak terkadang tidak fokus mendengarkan lawan bicara melainkan sambil melakukan hal lain seperti bermain hp, nonton TV dan lainnya. Selain itu sebagian siswa siswa kelas IV juga kadang masih ada yang menggunakan bahasa yang kasar (Enjha' Iye) saat berkomunikasi dengan orang yang lebih tua. Sehingga karakter toleransi pada siswa kelas IV tidak begitu sempurna meskipun telah berkategori membudaya. Karena siswa masih kurang menghargai orang lain baik dalam menggunakan bahasa atau ketika mendengarkan orang berbicara.

Sementara pada siswa kelas V hampir sama dengan siswa kelas IV, masih terdapat siswa yang menggunakan bahasa Enjha' Iye kepada orang tua, namun menggunakan bahasa Engghi Enten kepada orang lain. Serta terdapat siswa yang juga tidak mendengarkan lawan bicara dengan fokus seperti pada siswa kelas IV. Akan tetapi hal itu terjadi bila hal yang dibicarakan tidak terlalu penting. Sehingga meski demikian karakter toleransi yang dimiliki siswa kelas $\mathrm{V}$ masih tergolong membudaya namun masih perlu di tingkatkan lagi. Terutama dalam menggunakan bahasa saat berbicara. Sehingga nantinya karakter toleransi siswa kelas $\mathrm{V}$ benar-benar membudaya.

Berbeda dengan siswa kelas IV dan kelas V, karakter toleransi yang ada pada siswa kelas VI tegolong bagus. Siswa kelas V selalu bersikap menghargai kepada orang lain maupun dirinya sendiri baik saat berbicara maupun mendengarkan orang berbicara. Siswa juga lebih menggunakan bahasa yang lebih halus (Engghi Enten) saat berkomunikasi dengan orang tua maupun dnegan orang lain. Sehingga berdasarkan hasil observasi nilai 
yang diperoleh mengindikasikan bahwa karakter toleransi yang dimiliki oleh siswa kelas IV terkategori membudaya.

Hubungan bahasa madura yang digunakan oleh orang tua dengan karkter bersahabat atau komunikatif yaitu selain karakter toleransi ada karakter bersahabat atau komunikatif yang juga peneliti teliti. Pada siswa kelas IV karakter bersahabat dan komunikatif berkategori baik dan membudaya. Hal itu diketahui dari perolehan nilai hasil observasi yang telah dilakukan. Dimana semua siswa mengerjakan semua indikator pada karakter bersahabat atau komunikatif. Selain itu bahasa yang digunakan saat berkomunikasi adalah bahasa Madura dengan tingkatan Enjha' Iye kepada teman dan Engghi Enten kepada guru. Apa bila dengan orang lain menyesuaikan dengan tingkatan bahasa yang di gunakan oleh lawan bicara. Sehingga komunikasi berjalan dengan lancar

Karakter bersahabat atau komunikatif pada kelas $\mathrm{V}$ juga memiliki kategori yang baik atau membudaya. Siswa kelas V juga mengerjakan semua indikator dari karakter bersahabat atau komunikatif. Mereka aktif berkomunikasi dan bergaul dengan siswa yang lain di sekolah serta menjalin komunikasi yang baik dengan guru baik di dalam kelas maupun di luar kelas denga menggunakan bahasa Engghi Enten dan Enjha' Iye kapada temannya.

Sama halnya dengan siswa kelas IV dan V, siswa kelas VI juga memiliki karakter bersahabat atau komunikatif yang baik dan membudaya. Tidak kalah baik dan membudaya dengan karakter toleransi yang melekat pada diri siswa. Hal ini terbukti dengan adanya relasi yang baik antara siswa dengan guru dan antara siswa dengan siswa. Terciptanya komunikasi dengan bahasa Madura yang mereka gunakan membuat mereka mudah melakukan komunikasi. Sehingga karakter bersahabat atau komunikatif siswa kelas V berkategori membudaya.

Hubungan bahasa madura yang digunakan oleh orang tua dengan peduli soial yaitu seperti yang telah disampaikan di atas bahwa siswa kelas IV SDN Candi I tidak seluruhnya menggunakan bahasa yang baik (Engghi Enten) saat berkomunikasi dengan orang lain. Apa lagi dengan temannya, mereka menggunakan bahasa Enjha' Iye. Sehingga dalam melakukan intraksi sosial siswa masih tidak terlalu baik terutama dari segi berbicara yang berimbas pada karakter peduli sosial yang dimilikinya. Terdapat siswa yang tidak mengerjakan secara keseluruhan indikator peduli sosial, terutama pada indikator tenggang rasa atau menjenguk teman yang sakit. Masih terdapat siswa yang tidak menjenguk temannya ketika sedang sakit. Akan tetapi ada juga siswa yang menjenguk temannya yang sakit tetapi hanya yang rumahnya dekat dengan rumah siswa tersebut. Namun meski demikian karakter peduli sosial siswa kelas IV masih tergolong berkembang.

Sementara hal yang terjadi di kelas $\mathrm{V}$ juga terdapat siswa yang masih menggunakan bahasa Enjha' Iye saat berkomunikasi sehingga bahasa sehingga tidak melakukan indikator peduli sosial secara keseluruhan. Masih terdapat siswa yang tidak menjenguk temannya 
yang sakit. Selain itu ada juga siswa yang terkadang tidak mengembalikan atau menyerahkan barang yang di temukan kepada guru dengan catatan bila telah ditawarkan dulu pada anak-anak, kemudian tidaka ada yang mengaku, maka barulah kemudian di ambil. Sehingga karakter peduli sosial pada siswa kelas V masih tergolong mulai berkembang dan perlu penguatan untuk dapat membudaya. Dengan menggunakan bahasa yang baik, akan mengangkat derajad seseorang sehingga rasa kepedulian orang akan bertambah, begitu juga sebaliknya.

Berbeda dengan siswa kelas VI, mereka menggunakan bahasa Engghi Enten saat berkomunnikasi. Sehingga dapat berinteraksi social dengan baik dan mengerjakan semua indikator dari peduli sosial. Meskipun terdapat siswa yang hanya menjenguk temannya yang sakit yang rumahnya hanya dekat dengan siswa tersbut. Namun hal tersebut masih patut di apresiasi dari pada tidak menjenguk temannya yang sakit sama sekali. Sehingga karakter peduli sosial kelas VI tergolong membudaya.

Berhubung dengan dikeluarkannya Peraturan Menteri Pendidikan dan Kebudayaan Nomor 20 Tahun 2018 tentang ditetapkannya proses pembelajaran yang di dalamnya harus mengandung nilai-nilai karakter, maka guru dituntut untuk bisa menyelipkan nilai nilaikarakter di setiap pembelajaran yang dilakukan. Karakter-karakter yang harus ditanamkan kepada siswa terdiri dari 18 macam karakter. Di antara semua karakter yang ada, terdapat tiga karakter yang berhubungan dengan bahasa, diantaranya karakter toleransi, bersahabat atau komunikatif, dan peduli sosial.

Dari hasil penelitian yang telah dilakukan oleh peneliti terkait hubungan bahasa Madura yang digunakan oleh orang tua terhadap karakter siswa Kelas IV, V, dan VI SDN Candi I, di peroleh bahwa siswa menggunakan bahasa Enjha' Iye dan Engghi Enten saat berkomunikasi. Ada sebagian siswa yang masih menggunakan bahasa dengan tingkatan Enjha' Iye kepada orang tuanya dan orang asing yang mereka temui. Ada juga yang hanya menggunakan Enjha' Iye hanya pada orang tuanya. Sementara orang tua kepada siswanya menggunakan bahasa Madura dengan tingkatan Enjha' Iye. Sehingga anak sering meniru bahasa yang digunakan oleh orang tua ketika berbicara baik kepada orang lain. Akan tetapi orang tua selalu menekankan kepada anaknya untuk menggunakan tingkatan Engghi Enten untuk berbicara dengan orang lain.

Dari tiga karakter yang peneliti teliti yang paling dipengaruhi oleh bahasa Madura yang digunakan oleh orang tua terhadap karakter siswa Kelas IV, V, dan VI adalah karakter bersahabat atau komunikatif. Karakter tersebut adalah karakter yang paling menonjol dari ketiga karakter yang peneliti teliti yang dipengaruhi oleh bahasa Madura yang digunakan oleh orang tua. Sementara dua karakter lainnya (toleransi dan peduli sosial) juga masih tergolong berkembang, namun perlu ditingkatkan. Sehingga semakin baik bahasa yang digunakan maka akan semakin baik pula tiga karakter tersebut. Hal ini sesuai dengan apa yang disampaikan oleh Solin (2010) menyatakan bahwa semakin baik 


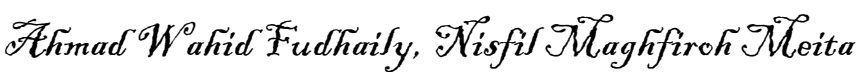

Penggunaan Bahasa Madura yang digurakan oleh Orang Tua terkadap Karalter Siswa

penggunaan bahasa dan semakin teliti pilihan bahasa yang digunakan maka semakin bagus pula karakternya.

Meskipun siswa Kelas IV, V, dan VI SDN Candi I berkategori membudaya pada karakter toleransi, bersahabat atau komunikatif, dan peduli sosial, bukan berarti karakterkarakter lain juga berkategori membudaya. Namun siswa yang berkategori membudaya pada tiga karakter yang peneliti teliti, bisa jadi pada karakter lain hanya berkembang atau mulai berkembang saja. Atau sebaliknya siswa yang hanya berkategori berkembang atau mulai berkembang pada karakter torelarnsi, bisa jadi berkategori membudaya pada karakter yang lain. Karena peneliti hanya fokus meneliti pada tiga karakter saja, sementara karakter sendiri ada 18 macam karakter.

\section{KESIMPULAN}

Berdasarkan hasil penelitian yang telah dilakukan maka penulis dapat menarik kesimpulan mengenai penggunaan bahasa yang digunakan orang tua terhadap karakter siswa Kelas IV, V, dan VI SDN Candi 1 bahwa bahasa yang digunakan adalah bahasa Madura dengan tingkatan Enjha' Iye dan Engghi Enten. Karakter toleransi, bersahabat atau komunikatif dan peduli sosial yang dimiliki oleh siswa juga telah termasuk kategori membudaya. Sehingga semakin baik bahasa yang digunakan maka akan semakin baik pula karakter yang dimiliki oleh siswa terutama pada karakter bersahabat atau komunikatif.

\section{DAFTAR PUSTAKA}

.(2008). Kongres I Bahasa Madura. Pamekasan.

Afifudin, H. dan Saebani, Beni Ahmad. (2012). Metodologi Penelitian Kualitatif. CV. Pustaka Setia. Bandung.

Bachri. Bachtiar S. (2010). Meyakinkan Validitas Data Melalui Triangulasi Pada

Penelitian Kualitatif. Jurnal Teknologi Pendidikan, Vol. 10 Nomor 1, April 2010 Hlm, 46-62. Universitas Negeri Surabaya.

Devianty, Rina. (2017). Peran Bahasa Idonesia dan Bahasa Daerah dalam Pendidikan Karakter. Medan.

Gumilang, Galang Surya. (2016). Metode Penelitian Kualitatif Dalam Bidang Bimbingan

Dan Konseling. Jurnal Fokus Konseling Volume 2 No. 2, Agustus 2016 Hlm. 144159. Kediri.

H, Tri Utami, dkk. (2019). Pengaruh Kecerdasan Emosional Terhadap Sikap Peduli Sosial SIswa di SMP Negeri 1 Palembang. Jurnal Bhinneka Tunggal Ika, Volume 6, Nomor 1, Mei 2019, hlm 17. Palembang.

Haryati, Sri. (2016). PENDIDIKAN KARAKTER DALAM KURIKULUM 2013.

Bangkalan

Lestari, Puji Nunik. (2015). Pengaruh Kebiasaan Menggunakan Bahasa Jawa Terhadap

Hasil Belajar Siswa Smk Purnama 2 Banyumas. Semarang.

Munawaroh. (2012). Panduan Memahami Metodologi Penelitian. Intimedia. Malang. 


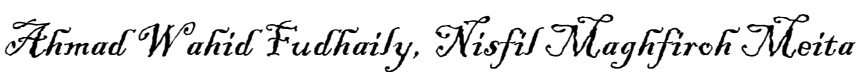

Penggunaan Bahasa Madura yang digurakan oleh Orang Tua terkadap Karalter Siswa

Nurlaila, Maryam. (2016). Pengaruh Bahasa Daerah (Ciacia) Terhadap Perkembangan Bahasa Indonesia Anak Usia 2 Sampai 6 Tahun Di Desa Holimombo Jaya. Jurnal Retorika, Volume 9, Nomor 2, Agustus 2016, hlm. 90-163. Baubau.

Peraturan Menteri Pendidikan dan Kebudayaan Republik Indonesia Nomor 20 Tahun 2018

Pendidikan, Tim Pusat Penelitian. (2019). Model Penilaian Karakter. Pusat Penilaian Pendidikan. Jakarta.

Prabowo, Aan, dan Heriyanto. (2013). Analisis Pemanfaatan Buku Elektronik (E-Book) Oleh Pemustaka Di Perpustakaan SMA Negeri 1 Semarang. Jurnal Ilmu Perpustakaan Volume 2, Nomor 2, Tahun 2013 Halaman 1-9.

Putra, Nusa. dan Lisnawati, Santi. (2012). Penelitian Kualitatif Pendidikan Agama Islam. PT Remaja Rosdakarya. Bandung.

Rahman, Astuti. (2016). Pengaruh Bahasa Daerah Terhadap Hasil Belajar Bahasa Indonesia Peserta Didik Kelas 1 Sd Inpres Maki Kecamatan Lamba-Leda Kabupaten Manggarai Timur Dalam Auladuna: Jurnal Pendidikan Dasar Islam Vol. 3 No. 2, December 2016, pp. 7-79. Makasar.

Rohullah, Ratu. (2017). Pengaruh Perilaku Bahasa Dalam Masyarakat Terhadap Mutu Pendidikan dan Perkembangan Sikap/Karakter Pada Anak Usia Dini. Dalam ELIC 2017 The 1st Education and Language International Conference Proceedings Center for International Language Development of Unissula May 2017, p.692-702.

Solin, Mutsyuhito. (2010). Peranan Bahasa Indonesia dalam Membangun Karakter Bangsa. Medan.

Sugiyono. (2012). Metode Penelitian Kuantitatif, Kualitatif, dan Kombinasi (Mixed Methods). Afabeta.cv. Bandung.

Sugiyono. (2012). Metodologi Penelitian Pendidikan (Pendekatan Kuantitatif, Kualitatif, dan $R \& D)$. Alfabeta.cv. Bandung.

Sulasmono, Putut. (2017). The Integration Of Local Cultural Wisdom Values In Building The Character Education Of Students. International Journal of Education and Research Vol. 5 No. 6 June 2017.

Sulistyaningsih. (2012). Metodologi Penelitian Kebidanan Kuantitatif-Kualitatif. Graha Ilmu. Yogyakarta.

Supriyanto, Agus dan Wahyudi, Amien. (2017). Skala Karalter Toleransi: Konsep dan Operasional Aspek Kedamaian, Menghargai Perbedaan dan Kesadaran Indiviidu. Jurnal Ilmiah Counsellia, Volume 7, Nomor 2, Nopember 2017 : 61-70.

Sutarna, Nana. Pendidikan Karakter Siswa Sekolah Dasar. 2018. Pustaka Diniyah. Yogyakarta.

Utami, Tri Setia. (2017). Upaya Meningkatkan SIkap Komunikatif dan Prestasi Belajar Pada Mata Pelajaran Bahasa Indonesia Materi Menulis Laporan Pengamatan Melalui Model Kooperatif Tipe Two Stay Two Stray di Kelas V MIM Karanglo. Purwokerto.

Wahidmurni. (2017). Pemaparan Metode Penelitian Kuantitatif. Malang.

Werang, Basilius Redan. (2015). Pendekatan Kuantitatif dalam Penelitian Sosial. Calpulis. Yogyakarta. 